\title{
The impact of healthy workplaces on employee satisfaction, productivity and costs
}

\author{
Theo van der Voordt
}

Faculty of Architecture and the Built Environment, Delft University of Technology, Delft, The Netherlands and Center for People and Buildings,

\section{Impact of healthy workplaces}

\author{
Delft, The Netherlands, and \\ Per Anker Jensen \\ DTU Management Engineering, Technical University of Denmark, \\ Lyngby, Denmark
}

\begin{abstract}
Purpose - This paper aims to explore the added value of healthy workplaces for employees and organizations, in particular regarding employee satisfaction, labour productivity and facility cost.

Design/methodology/approach - The paper is based on a narrative review of journal papers and other sources covering the fields of building research, corporate real estate management, facilities management, environmental psychology and ergonomics.

Findings - The review supports the assumption of positive impacts of appropriate building characteristics on health, satisfaction and productivity. Correlations between these impacts are still underexposed. Data on cost and economic benefits of healthy workplace characteristics is limited, and mainly regard reduced sickness absence. The discussed papers indicate that investing in healthy work environments is cost-effective. Originality/value - The findings contribute to a better understanding of the complex relationships between physical characteristics of the environment and health, satisfaction, productivity and costs. These insights can be used to assess work environments on these topics, and to identify appropriate interventions in value-adding management of buildings and facilities.
\end{abstract}

Keywords Well-being, Workplace, Health, Productivity, Satisfaction, Cost, Added value

Paper type Literature review

\section{Introduction}

The WHO defines health as "a state of complete physical, mental and social well-being and not merely the absence of disease or infirmity". As such, a healthy workplace can be defined as a workplace that contributes to the physical, mental and social well-being of its users. Health is the result of a complex interaction between the physiological, psychological, personal and organizational resources available to individuals and the stress placed upon them by their physical and social environment at work and home (Clements-Croome, 2018).

(C) Theo van der Voordt and Per Anker Jensen. Published by Emerald Publishing Limited. This article is published under the Creative Commons Attribution (CC BY 4.0) licence. Anyone may reproduce, distribute, translate and create derivative works of this article (for both commercial and noncommercial purposes), subject to full attribution to the original publication and authors. The full terms of this licence may be seen at http://creativecommons.org/licences/by/4.0/legalcode

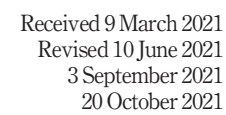

Accepted 27 October 2021 
JCRE 25,1

Well-being reflects one's feelings about oneself in relation to the world, personal feelings about motivation, competence, aspirations and degree of personal control.

\subsection{Impact of the physical environment on health and well-being}

The past decades show a growing awareness of the impact of the physical environment on peoples' health and well-being, both in academic research and in professional publications. This may be because of the shift from a one-sided focus on cost reduction to a more holistic and integrated value-based approach and an optimal balance between costs and benefits of interventions in buildings, facilities and services (Jensen and Van der Voordt, 2017). Besides, people have become more aware of the impact of health and well-being on our quality of life and the risk of health complaints, illness or - in worst cases - burnout (Appel-Meulenbroek et al., 2020). The relationship between physical workplace characteristics and health and wellbeing has been explored by a variety of studies, using reviews of the literature (Forooraghi et al., 2020; Van der Voordt, 2021), surveys (Cordero et al., 2020), case studies (Bauer, 2020) and conducting short-term experiments using mobile devices (Nelson and Holzer, 2017).

It appears that in particular a poor indoor climate, noise and distraction have a negative impact on employees' health and well-being, whereas appropriate opportunities to communicate and to concentrate and contact with nature contribute to a healthy workplace. In a survey of 2,000 office workers, occupants reported preferences for lots of natural light, access to outdoor spaces, contemplation spaces, support from colleagues and private as well as collaborative spaces, whereas the main irritants were noise in open-plan areas, lack of natural light, lack of colour, lack of greenery, lack of artwork, lack of fresh air, no personal control of temperature, lack of privacy, clutter and inflexible space (British Council for Offices, 2018).

Another frequently assessed factor is office type. A literature review by Colenberg et al. (2020) on the relationship between interior office space (layout, furniture, light, greenery, controls and noise) and employees' physical, psychological and social well-being showed that open-plan offices, shared rooms and higher background noise are negatively related to health. Positive relationships were found between physical well-being and aspects that encourage physical activity; between physical/psychological well-being and (day)light, individual control and real/artificial greenery; and between social well-being and small shared rooms.

Other influencing factors on health and well-being are important as well, such as the context (cultural, social, economic, political), personal characteristics (age, gender, lifestyle), organizational issues (leadership, personal support) and job characteristics (work load, (mis) fit between demands and resources). The European Agency for Safety and Health at Work (2014) warns for a disbalance between high job demands and available job resources. Too little time, too much work and tight deadlines are the most widely recognized risk factors, resulting in sleep disturbance, changes in mood, fatigue, headaches and stomach irritability.

\subsection{Relationship between healthy workplaces and other values}

Healthy workplaces that support employees' health and well-being can be a goal in itself, but may also have intended or unintended effects on other values, such as employee satisfaction, productivity, costs, corporate image and risk. Vice versa, values such as sustainability may contribute to health and well-being. For instance, green buildings are supposed to be healthier than non-green buildings, because of its focus on the triple $\mathrm{P}$ of people, planet and profit. Interrelationships between healthy workplaces and other values are much less studied. This paper aims to reduce this gap in our knowledge, and to answer two research questions: What is the relationship between healthy workplaces and employee satisfaction, productivity and costs? And which evidence is available for these relationships? 
These three values turned out to be most frequently prioritized in interviews with corporate real estate and facility managers (Van der Voordt and Jensen, 2014). It is hypothesized that health, satisfaction and productivity go hand in hand. Furthermore, because of the high staff costs compared to facility costs, it is hypothesized that healthsupportive interventions are cost-effective. Figure 1 visualizes the key topics of this paper in blue.

\section{Methods}

Because of a limited number of available publications, it was decided to select a number of leading journals in the field and to conduct a narrative review (Green et al., 2006; Ferrari, 2015). In our earlier review of environmental impact factors on healthy workplaces (Jensen and Van der Voordt, 2020), we checked four facilities management and corporate real estate management oriented journals in a 10-year period, covering 2008-2017: Journal of Corporate Real Estate, Corporate Real Estate Journal, Facilities and the Journal of Facilities Management. For the current paper, we extended our search to the period 2018-2021 and to other journals, based on paper citations and journal titles. We also screened the last six volumes of Applied Ergonomics, Building and Environment, Building Research and Information, Environment and Behavior, Ergonomics, Intelligent Buildings International and Journal of Environmental Psychology on the keywords workplace, health, well-being, satisfaction, productivity and cost.

All papers from the screened journals that discuss health in connection to workplace characteristics and satisfaction, productivity and/or cost were included in this review. This has resulted in a selection of 45 papers on health and satisfaction and/or productivity. Because very few scientific papers related to facility cost were found, we have included relevant industry reports and other publications. Papers that discuss the relationship between the physical environment and either health, satisfaction, productivity or cost, without discussing any interrelationships between these variables, have been excluded.

\section{Findings on the added value of healthy workplaces}

\subsection{Employee satisfaction}

Table 1 summarizes the research topics, methods and findings of eight papers that discuss relationships between physical characteristics of the built environment, health and satisfaction, ranked by year and per year in alphabetical order of the first author. Five out of eight studies investigate the impact of office type and workspaces. The other studies focus

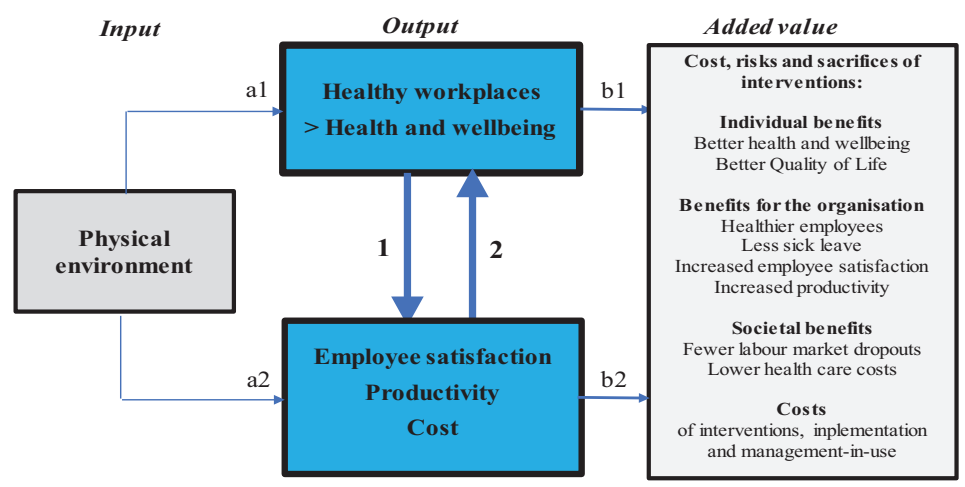

Figure 1. Key topics of this paper 


\begin{tabular}{lll}
\hline Study & Methodology & Research topics \\
\hline Bodin & Questionnaire survey; & Impact of office types on \\
Danielsson & 469 employees in seven & health, well-being and \\
and Bodin & offices from 26 & job satisfaction \\
(2008) & companies in Sweden &
\end{tabular}

\section{2}

Seddigh

1,241 respondents from
five organizations in

Sweden in six office types

Herbig

$\begin{array}{ll}\text { et al. (2016) } & \text { Questionnaire survey in } \\ \text { two buildings; } 207 \text { office }\end{array}$ employees in a company in Germany. The older building had small-sized offices with 1-4 employees, and the new building had open-plan

Eichholtz Questionnaire surveys

et al. (2019) before and after a relocation of a municipality in the Netherlands from enclosed office spaces to a new building with open-plan, a strong focus on sustainability and natural ventilation

Tan et al. Questionnaire survey; (2020) 195 respondents, including 121 working underground and 74 working above-ground in Singapore

Wijk et al. (2020)

Table 1.

Health and wellbeing and satisfaction (eight studies)
Interaction between the need for concentration, distraction, cognitive stress, emotional exhaustion, depersonalization, personal efficiency and general health

Impact of office space occupation psychosocial work characteristics, and environmental satisfaction on physical and mental health

Impact of environmental conditions in the workplace on health and job satisfaction

Relationship between mental health, fatigue and satisfaction with workspaces and

transitional spaces such as corridors

Relationship between indicators of sense of coherence (SOC) meaningfulness, manageability and comprehensibility - and health, well-being and work satisfaction
Findings

Highest health status among employees in cell- and flex-offices; lowest health status in medium-sized and small openplan offices. Highest job satisfaction in cell, flex and shared offices; lowest job satisfaction in combi-offices, followed by medium-sized open-plan No significant differences in the outcome variables between different types of open-plan. Employees with high need for concentration reported more distraction in all office types, except in cell, and more cognitive stress in all office types except cell and flexoffices

Effect of office space occupation on employee health was mediated by stressors and environmental satisfaction. More persons per enclosed office space was associated with adverse health effects. Increasing acoustic disturbances and feelings of loss of autonomy and discretion had a negative impact on health

Significant improvement in the perceived environmental conditions and health of the relocated workers and a drop in sick building syndrome (SBS) The largest environmental improvements concerned the perceived air quality

Lower perceived confinement in transitional spaces was associated with better mental health and lower workload fatigue. Underground workers reported lower levels of physical and emotional fatigue. Among the participants working in aboveground offices, effects were stronger for those with higher levels of claustrophobia

Reduced work satisfaction, unchanged health and well-being. The reduction in satisfaction was smaller among employees with high meaningfulness in the relocation process. All SOC indicators were positively associated with overall health, well-being and satisfaction 


\begin{tabular}{|c|c|c|c|c|}
\hline Study & Methodology & Research topics & Findings & $\begin{array}{l}\text { mpacl of } \\
\text { healthy }\end{array}$ \\
\hline & $\begin{array}{l}\text { workplaces (ABW) in } \\
\text { Sweden }\end{array}$ & & & workplaces \\
\hline \multirow[t]{2}{*}{$\begin{array}{l}\text { Elnaklah } \\
\text { et al. }(2021)\end{array}$} & \multirow{2}{*}{$\begin{array}{l}\text { Repeated surveys in an } \\
\text { organization with } 120 \\
\text { employees before and } \\
\text { after moving to a new } \\
\text { certified green building } \\
\text { (GB) }\end{array}$} & \multirow{2}{*}{$\begin{array}{l}\text { Effects on occupant } \\
\text { perception of indoor } \\
\text { environmental quality } \\
\text { (IEQ, i.e. ventilation, } \\
\text { thermal comfort, lighting } \\
\text { and daylighting, noise, } \\
\text { acoustics) on thermal } \\
\text { comfort and prevalence } \\
\text { of SBS }\end{array}$} & \multirow{2}{*}{$\begin{array}{l}\text { Significant differences in thermal } \\
\text { conditions enhanced occupant thermal } \\
\text { comfort in the GB. Odour, mental } \\
\text { concentration and glare were perceived } \\
\text { to be poor in the GB and associated } \\
\text { with an increase in the prevalence of } \\
\text { SBS symptoms }\end{array}$} & 33 \\
\hline & & & & \\
\hline $\begin{array}{l}\text { Hodzic } \\
\text { et al. }(2021)\end{array}$ & $\begin{array}{l}\text { Surveys of up to } 247 \\
\text { employees before and } 2 \\
\text { and } 12 \text { months after a } \\
\text { relocation to a new } \\
\text { headquarters of a large } \\
\text { company in Austria }\end{array}$ & $\begin{array}{l}\text { Distractions after } \\
\text { moving to an activity- } \\
\text { based flexible office }\end{array}$ & $\begin{array}{l}\text { Moving to the flex office had negative } \\
\text { effects on distraction, work } \\
\text { engagement, job satisfaction and } \\
\text { fatigue. The negative effects of } \\
\text { distraction were more pronounced in } \\
\text { situations of increased time pressure } \\
\text { and unpredictability }\end{array}$ & \\
\hline
\end{tabular}

on environmental conditions, sense of coherence or green buildings. The findings show positive but also contradictory connections between office type; health and well-being; and employee satisfaction. Open-plan seems to have a negative impact, which can be partly compensated by improved environmental conditions. High density and poor acoustics affect health and satisfaction in a negative way. The green building study showed mixed results. Personal characteristics make a difference as well. Employees with high need for concentration report more distraction in all office types, except in cell, and more cognitive stress in all office types except cell and flex-offices. People suffering from claustrophobia perceive stronger effects.

\subsection{Labour productivity}

The findings on relationships between health and well-being and labour productivity are summarized in Table 2. Four studies focus on office type and workplace concept (open-plan, work pattern-office type fit, high-performance hub, variety of workplaces). Five studies investigated the impact of indoor air quality (IAQ) and related issues such as thermal comfort and look-and-feel. Four studies focus on sit-stand/adjustable workstations. The other studies show a variety of research topics, i.e. the influence of a healing office design concept, wind-inducing motion of tall buildings, green buildings, workplace safety, biophilia, plants and time spent in the office. The findings show significant positive but also mixed impacts of IAQ, "green" buildings and sit-stand work on both health and productivity. Health and productivity are usually discussed separately; correlations between health and productivity were only explored in two studies. Interrelationships are affected by job demands and job stress

\subsection{Satisfaction and productivity}

Table 3 summarizes the findings from 17 studies on health and well-being and both satisfaction and productivity. Independent variables include office types, non-territorial workspaces, proximity, impact of break out areas, storage space, adopting the WELL 


\begin{tabular}{lll}
\hline Study & Methodology & Research topics \\
\hline Karakolis and & Literature review & Impact of sit-stand \\
Callaghan & & workstations (SSW) on \\
(2014) & & worker discomfort and \\
& productivity
\end{tabular}

\section{4}

\section{Al Horr et al. Literature review (2016)}

Lamb and Longitudinal study with Kwok (2016) questionnaire surveys; 114 participants from 66 different buildings completing 2,261 surveys across a period of eight months

Jinnett et al. Questionnaire surveys; (2017) 16,926 employees from 314 companies in the USA

Lamb and Kwok (2017)

MacNaughton et al. (2017)
Table 2.

Health and wellbeing and labour productivity (20 studies)
Literature review, including own research, simulation studies and surveys

Cognitive tests of higher order decision-making performance; 109 participants working in 10 office buildings in the USA. Six building had been renovated and obtained LEED certification; four buildings had no green certification
Impact of working in a green-certified building on cognitive function and health. IEQ parameters were monitored during the tests
Impact of IEQ, biophilia, Thermal comfort, IAQ, office views, look and feel (including colour), location and amenities on occupant productivity

Effects of inadequate IEQ on work performance and well-being in windexcited tall buildings in New Zealand

Impact of workplace safety, employee health and job demands on productivity, measured by absenteeism and presenteeism in the past four weeks, in a worksite wellness program Impact of wind-induced motion of tall buildings ("sopite syndrome") on productivity loss and well-being

layout, noise and acoustics were found to be highly significant in affecting occupant productivity. Occupant comfort directly relates to the physical factors of the indoor environment

Environmental stress not only reduces the cognitive capacity for work, but also the rate of work. Improving IEQ is likely to produce small but pervasive increases in productivity

Poor workplace safety and employees' chronic health conditions contributed to absenteeism and job performance The impact was influenced by the physical and cognitive difficulty of the job

Sickness and productivity loss because of wind-induced building motion are highly variable, depending on the local weather climate, but are likely to be significant in the long term and can go up to $30 \%$ reduction in work performance

Participants in green-certified buildings scored $26 \%$ higher on cognitive function tests and had $30 \%$ fewer sick building symptoms than those in noncertified buildings. This could partially be explained by IEQ parameters, but the findings indicate that the benefits of green certification go beyond measurable IEQ factors 


\begin{tabular}{|c|c|c|c|c|}
\hline Study & Methodology & Research topics & Findings & $\begin{array}{l}\text { clor } \\
\text { lthy }\end{array}$ \\
\hline $\begin{array}{l}\text { Garland et al. } \\
\text { (2018) }\end{array}$ & $\begin{array}{l}\text { Self-administered } \\
\text { questionnaires, and } \\
\text { response to repeated } \\
\text { micro-polling over one } \\
\text { year, in an office building } \\
\text { in the USA, with workers } \\
\text { having adjustable } \\
\text { workstations (AWS) and } \\
\text { a control group without } \\
\text { AWS }\end{array}$ & $\begin{array}{l}\text { Health impact of } \\
\text { adjustable workstations } \\
\text { (AWS) }\end{array}$ & $\begin{array}{l}47 \% \text { of participants with AWS } \\
\text { reported decline in upper back, } \\
\text { shoulder and neck discomfort; } 88 \% \\
\text { of AWS participants reported } \\
\text { convenience to use, } 65 \% \text { reported } \\
\text { increased productivity: } 65 \% \\
\text { reported positive impact outside } \\
\text { the workplace }\end{array}$ & workplaces \\
\hline $\begin{array}{l}\text { Chambers } \\
\text { et al. }(2019)\end{array}$ & Literature review & $\begin{array}{l}\text { Effect of sit-stand desks } \\
\text { (SSDs) on office workers' } \\
\text { behavioural, physical, } \\
\text { psychological and health } \\
\text { outcomes, work } \\
\text { performance, discomfort } \\
\text { and posture }\end{array}$ & $\begin{array}{l}\text { SSDs effectively change } \\
\text { behaviours, but these changes only } \\
\text { mildly affect health outcomes. } \\
\text { SSDs seem most effective for } \\
\text { discomfort and least for } \\
\text { productivity }\end{array}$ & \\
\hline $\begin{array}{l}\text { Isham et al. } \\
\text { (2019) }\end{array}$ & Literature review & $\begin{array}{l}\text { Well-being and } \\
\text { productivity }\end{array}$ & $\begin{array}{l}\text { Well-being showed to be linked to } \\
\text { higher levels of labour } \\
\text { productivity. Productivity growth } \\
\text { may also have detrimental effects } \\
\text { on well-being }\end{array}$ & \\
\hline $\begin{array}{l}\text { Wargocki } \\
\text { (2019) }\end{array}$ & Literature review & $\begin{array}{l}\text { Impact of IAQ on health } \\
\text { and productivity }\end{array}$ & $\begin{array}{l}\text { Doubling the outdoor air supply } \\
\text { rate can reduce illness and sick } \\
\text { leave prevalence by roughly } 10 \% \\
\text { and increase the productivity of } \\
\text { office work by roughly } 1.5 \%\end{array}$ & \\
\hline Bauer (2020) & $\begin{array}{l}\text { Before/after study of the } \\
\text { adoption of the Healing } \\
\text { Offices design concept } \\
\text { (ten qualities), based on } \\
\text { observations, ten } \\
\text { interviews and a survey } \\
\left(\mathrm{N}_{\text {before }}=92, \mathrm{~N}_{\text {after }}=120\right)\end{array}$ & $\begin{array}{l}\text { Impact of a Healing } \\
\text { Office on perceived } \\
\text { health, engagement, } \\
\text { comfort and productivity }\end{array}$ & $\begin{array}{l}\text { Increased objective quality of the } \\
\text { work environment regarding } \\
\text { sustainability, diversity, nature } \\
\text { and the possibilities to move and } \\
\text { relax. Increased subjective } \\
\text { experience regarding feelings of } \\
\text { inspiration, comfort and energy, } \\
\text { more physical activity and } \\
\text { personal contact, increased } \\
\text { teamwork and productivity }\end{array}$ & \\
\hline $\begin{array}{l}\text { Hähn et al. } \\
\text { (2020) }\end{array}$ & $\begin{array}{l}\text { Survey; } 40 \text { occupants in a } \\
\text { modern office building } \\
\text { with two potted plants } \\
\text { per person introduced } \\
\text { into individual offices, } \\
\text { and eight in break-out } \\
\text { spaces }\end{array}$ & $\begin{array}{l}\text { Perceived health, well- } \\
\text { being and performance }\end{array}$ & $\begin{array}{l}\text { Plants in offices had significantly } \\
\text { positive effects on occupants } \\
\text { perceived attention, creativity, } \\
\text { satisfaction and productivity; } \\
\text { plants' removal elicited } \\
\text { significantly negative effects in } \\
\text { perceived attention, productivity, } \\
\text { stress and efficiency. Planting had } \\
\text { no significant effect on perceived } \\
\text { health, tiredness, motivation or } \\
\text { well-being }\end{array}$ & \\
\hline $\begin{array}{l}\text { Kaushik et al. } \\
\text { (2020) }\end{array}$ & $\begin{array}{l}\text { Post-occupancy } \\
\text { evaluation (POE) over } \\
12 \text { months in an office } \\
\text { with } 40 \text { occupants in }\end{array}$ & $\begin{array}{l}\text { Effects of IEQ on thermal } \\
\text { comfort and occupant } \\
\text { productivity and } \\
\text { establishing }\end{array}$ & $\begin{array}{l}\text { Nine IEQ parameters were ranked } \\
\text { according to the degree of effect on } \\
\text { occupant thermal comfort and } \\
\text { productivity. Temperature had the }\end{array}$ & \\
\hline & & & (continued) & \\
\hline
\end{tabular}




\begin{tabular}{|c|c|c|}
\hline Study & Methodology & Research topics \\
\hline & $\begin{array}{l}\text { Quatar using sensors to } \\
\text { measure environmental } \\
\text { quality as well as online } \\
\text { survey every fortnight }\end{array}$ & $\begin{array}{l}\text { mathematical } \\
\text { relationships }\end{array}$ \\
\hline Lu et al. (2020) & $\begin{array}{l}\text { Experimental study with } \\
18 \text { office workers in a } \\
\text { closed chamber } \\
\text { simulating an ordinary } \\
\text { office and different } \\
\text { combination of } \\
\text { illumination levels and } \\
\text { colour temperatures }\end{array}$ & $\begin{array}{l}\text { Effects of illuminance } \\
\text { and colour temperature } \\
\text { on light comfort and } \\
\text { work efficiency }\end{array}$ \\
\hline
\end{tabular}

Marsh and Test of 50 employees in a French (2020) Workplace Performance Hub (WPH) and 20 employees in a control group, across a six-month period

Morrison and Longitudinal study with Smollan (2020) surveys covering 101 respondents and 24 interviews in an Australian law firm six month after moving to an open-plan office with follow-up 14 months later Soriano et al. Questionnaire and diary (2020) study; 83 office workers $(N=603$ time points) regarding work patterns, identified by using cluster analysis with Neufert's office-type classification

Wolkoff (2020) Literature review

Kar and Hedge (2021)
Experimental study in the USA, where 36 participants performed a 60-min computer typing task in two sit-stand workstation configurations
Impact of greater variety in workplaces, circadian lighting and biophilia on employee health, wellbeing and performance Impact of open-plan office on performance, wellbeing and collegial relationships

\section{Well-being and} performance

Dry eye symptoms and work performance in offices

Comparison of musculoskeletal discomfort, productivity, postural risks and perceived fatigue for a sit-stand-walk intervention between two workstation configurations
Findings

highest and relative humidity the second highest effect

Improving the illumination of the work environment helps to improve the light comfort. Reading efficiency is generally improved using a neutral colour temperature. The physiological evaluation indicated that illumination significantly affects the response of the visual centre

WPH participants experienced an increase in cognitive performance and a reduction in stress. They were more active and had a lower resting heart rate and saw a rise of $17 \%$ in innovation cycles during their stay

Positive outcomes relating to aesthetics, collegiality and communication were achieved through good technical design and thoughtful ergonomic assessment of the needs of employees and the requirements of their tasks

Work pattern-office type (mis)fit moderates the relationship between well-being and performance. The "fit" group shows four out of six positive associations; the "misfit" group shows only one out of six positive associations

Dry eyes are among the most reported acute health symptoms in modern offices

Perceived dry air in the work environment negatively affects work performance Musculoskeletal discomfort and perceived fatigue did not vary significantly between configurations. Postural risks for seated and standing work were significantly lower for a customized configuration, while productivity was significantly higher for a self-adjusted configuration 


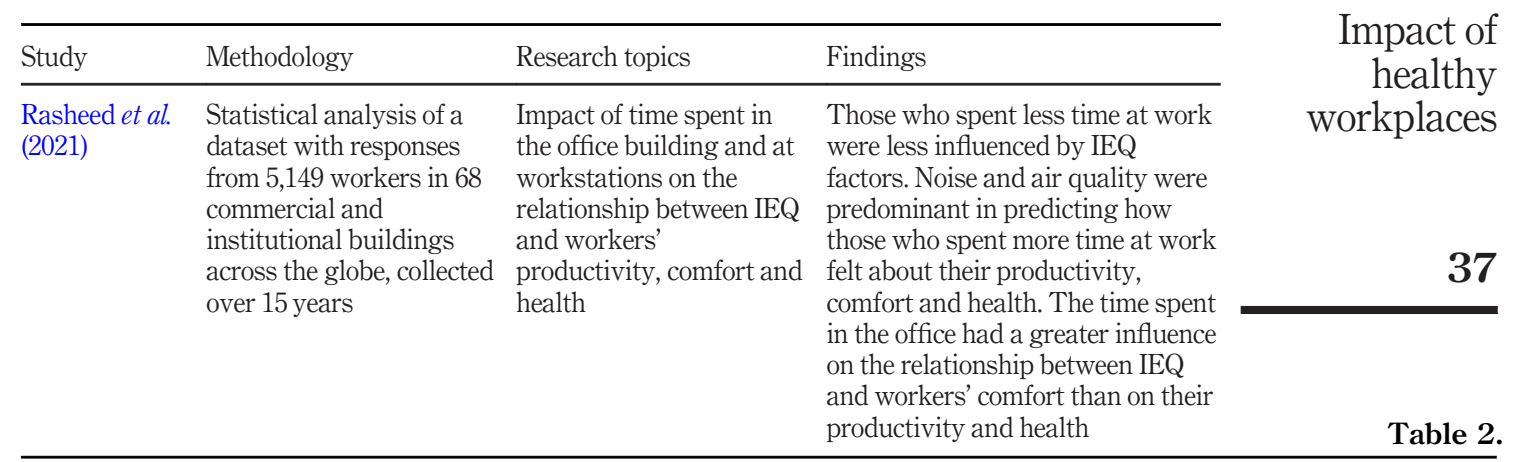

criteria, indoor environmental quality (IEQ), shading conditions, sit-stand workstations and plants. Here, too, health, satisfaction and productivity are mainly discussed separately and less regarding possible correlations. In general, activity-based workplaces are perceived to have a positive impact on satisfaction, partly because of better technical qualities regarding IEQ. Searching for a workplace needs time and reduces productivity. Personal control, easiness of interaction and communication, availability of break out areas, windows, sitstand workstations, comfort of furnishing, attractive IEQ, modern shading systems and applying to the WELL standard show to have a positive impact on both health and satisfaction, whereas distraction and lack of privacy are important predictors of productivity loss.

All presented studies on health in connection to satisfaction and/or productivity originate from Europe, USA, Australia and New Zealand.

\subsection{Applied research methods to study health and satisfaction and/or productivity}

The discussed papers on health and satisfaction and/or productivity show a variety of research designs and research methods (Table 4). Ten studies conducted a before-after study; four studies used an experiment in a lab setting. About $80 \%$ of the presented studies used a questionnaire survey, some of them as part of a mixed-methods approach with interviews and observations, identifying healthy or unhealthy office design qualities, scores on the WELL standard and data about toxic substances in the air. Measuring physical conditions such as the heart rate or skin temperature is rather rare.

\subsection{Financial costs and benefits}

Clements-Croome (2018) mentions a return on investment of $€ 5.7$ for every euro invested in well-being. However, not much quantitative data was found about the financial impact of changing the spatial layout, supporting new ways of working, providing more contact with nature or the introduction of sit-stand desks. This may be because of the difficulties to quantify the results of healthy workplaces. Various papers discuss the monetary costs and benefits of health-promoting programs such as stop-smoking programs or providing sports facilities and healthier nutrition. However, these topics are not related to physical characteristics of workplaces and are beyond the scope of this paper. Table 5 summarizes the findings from 11 publications. Different research methods are used, such as literature reviews, surveys and analysis of sickness absence data (8 out of 11 studies) and costs. Some studies focus on the impact of stress, without clear links to physical characteristics. Not all 


\begin{tabular}{lll}
\hline Study & Methodology & Research topics \\
\hline Candido et al. & $\begin{array}{l}\text { Surveys covering } 5,171 \\
\text { respondents in } 30\end{array}$ & $\begin{array}{l}\text { Impact of workspace } \\
\text { layout on satisfaction, } \\
\text { buildings in Australia }\end{array}$ \\
& $\begin{array}{l}\text { perceived comfort, } \\
\text { health and productivity }\end{array}$
\end{tabular}

Kimet al. (2016)

Reduced dataset of Candido et al. (2016); 3,974 respondents in 20 buildings

Haapakangas Questionnaire surveys et al. (2018a) in two offices in Sweden before and after relocations from private to open-plan

Haapakangas Questionnaire survey et al. (2018b) with 239 respondents a year after implementation of ABW in four offices in Sweden

Candido et al. Questionnaire surveys, spot measurements
IEQ and step-count monitoring in 10 offices before and after relocations from contemporary openplan to ABW

Groen et al. Survey data from (2019) 25,947 respondents and 191 organizations in the Netherlands

Comparison with findings from a similar study 10 years ago
Table 3.

Health and wellbeing, satisfaction and labour productivity (17 studies)
Effect of non-territorial working versus working in open-plan offices with assigned workplaces and ABW with desk-sharing on health, satisfaction and productivity

Impact of quiet spaces in open-plan offices on stress symptoms

Relationships between environmental perceptions and workspace use and selfrated productivity and well-being at work

Satisfaction, productivity and health

Findings

Respondents in ABW had the highest degree of satisfaction in terms of overall work area comfort and building satisfaction. Respondents in cell-offices had the highest degree of satisfaction in relation to privacy

Office layout allowing easiness of interaction with colleagues, the ability to adjust/personalize workspace, and the amount of storage space showed to be more important than desk ownership. The comfort of furnishing was identified as the strongest predictor of self-assessed health for shared-desk users

Perceived distractions increased in both organizations after the relocation. Negative effects on environmental satisfaction, perceived collaboration and stress only emerged in the openplan, where the number of quiet rooms was low

Satisfaction with the physical environment, privacy and communication had the strongest positive associations with productivity and well-being at work. Increased workspace switching was associated with higher productivity. An increase in time spent searching for a workspace was associated with lower productivity and well-being

ABW had significantly higher satisfaction results on key IEQ dimensions, perceived productivity and health

Relationship between satisfaction with buildings, facilities and services and perceived productivity support. Absence of health complaints was one aspect of productivity support
$38 \%$ of the variation of office employees' satisfaction with support of productivity could be explained by employee satisfaction with facilities, the organization, current work processes and personal- and job-related characteristics

Opportunities to concentrate and to communicate, privacy, level of openness and functionality, comfort and diversity of the workplaces are very important 


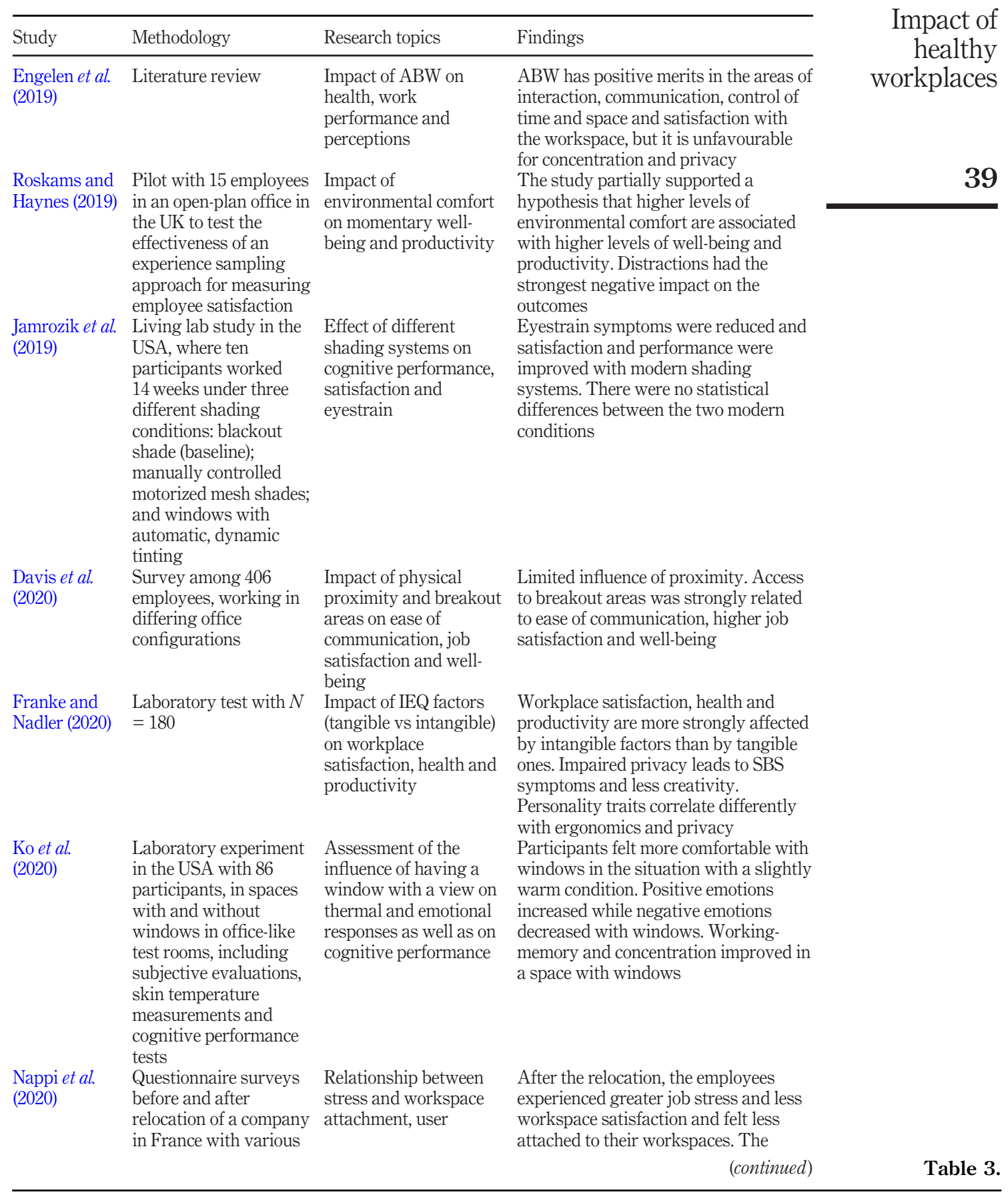




\begin{tabular}{lll}
\hline Study & Methodology & Research topics \\
\hline & office types, mostly & satisfaction and \\
open-plan and flex & productivity \\
Thatcher & Experimental study in & Impact of indoor plants \\
et al. (2020) & $\begin{array}{l}\text { a laboratory with } \\
\text { student participants, }\end{array}$ & on performance and \\
& well-being
\end{tabular}

Africa

Candido et al. Questionnaire surveys

(2021) with 1,121 respondents from nine offices in Australia, divided into four with open-plan and five with ABW. All buildings held a Green Building certification; two of them also held a WELL certification

Licina and Yildirim Online survey among (2021) employees in three companies in Switzerland before and after relocation to new office buildings

Satisfaction, productivity and health Comparison with benchmarks from a research database (Candido et al., 2016)

Occupant satisfaction, productivity and health during a transition to WELL-certified buildings

Current use and practices to support the implementation of sitstand workstations (SSWs)
Findings

perceptions of workspace support to labour productivity did not change In the laboratory study, the condition with indoor plants performed statistically better on three measures of work performance. These positive outcomes could not be replicated in two field studies using various proxy measures of performance and wellbeing

The buildings with WELL certification achieved the highest scores for overall satisfaction, workability, perceived productivity and health Offices with ABW had the highest scores on spatial comfort, thermal comfort, noise and privacy, personal control, comfort of furnishing, adjustability of the work area and space to collaborate

Significant increase in satisfaction in two out of three WELL buildings. The positive effect was evident for building cleanliness and furniture. WELL buildings usually did not attain the $80 \%$ standard satisfaction threshold. SBS symptoms and productivity scores revealed no significant differences, except that symptom of tiredness was lower in WELL buildings $40 \%$ of organizations provided SSWs on request, whereas $41 \%$ reported not using them appropriately. SSWs were perceived effective in reducing discomforts and increasing employees' satisfaction and productivity

Table 3.

Zerguine et al. Mix-method study, survey with 216 respondents from 150 organizations across 18 sectors as well as 17 interviews in Australia project data on financial costs and benefits has been tested scientifically on reliability and validity.

\section{Discussion and conclusions}

The discussed studies show a huge variety in environmental characteristics that influence health and well-being, employee satisfaction and labour productivity, such as office type, proximity, density, IEQ of IAQ, furniture (ergonomics, sit-stand desks), plants and personal control. Some studies focus on specific building types such as certified green buildings, WELL-certified buildings and tall wind-excited building, specific building components such as shading systems or specific interior elements such as sit-stand desks and furniture comfort. Research methods range from questionnaire surveys to before-after studies and laboratory experiments. Measuring physical conditions such as heart rates and skin temperature is still underexposed. Remarkably, most discussed papers present findings on 


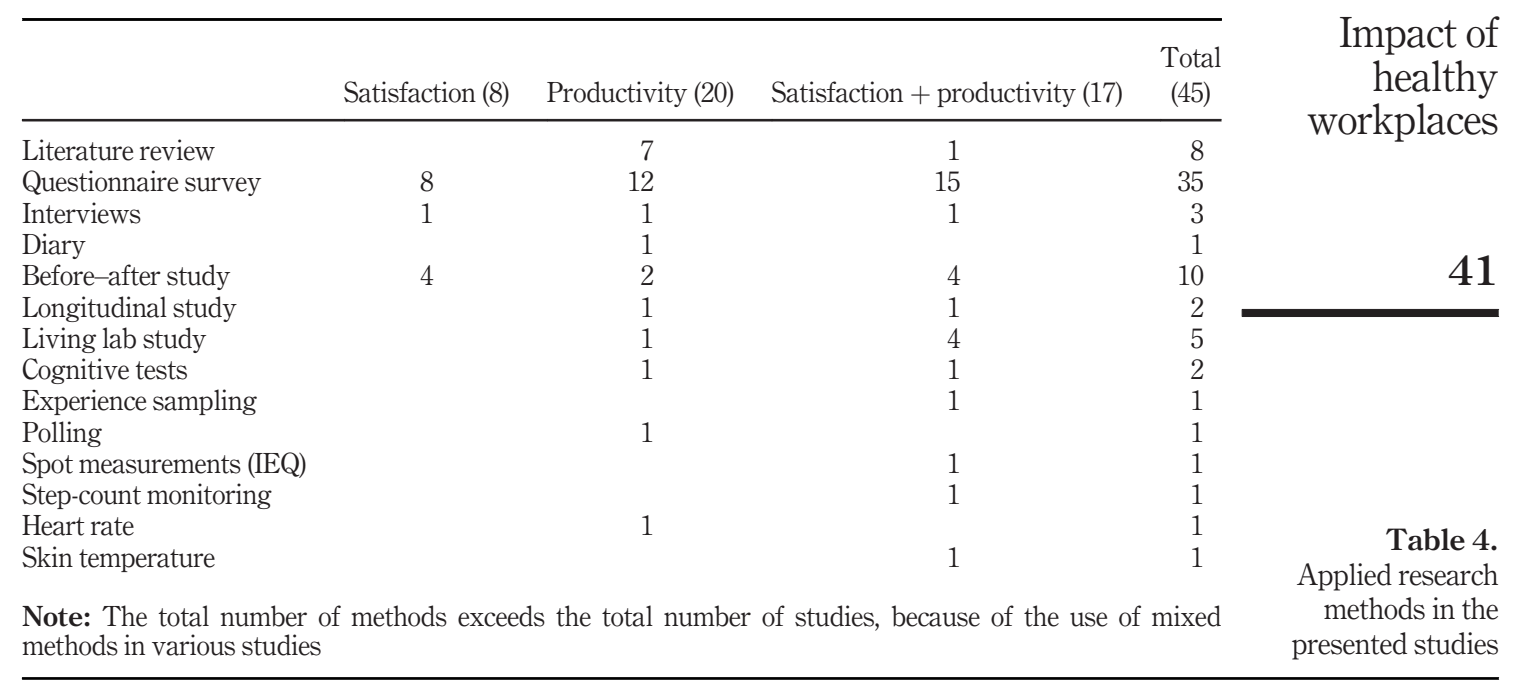

health and satisfaction and/or productivity without discussing correlations between health, satisfaction and productivity.

The reviewed studies indicate positive but also mixed and contradictory effects of healthy workplaces on satisfaction and productivity. Overall, a healthy IAQ, opportunities for communication, concentration and privacy, availability of break-out rooms, an attractive look-and-feel, ergonomic furniture, contact with nature and plants go hand-in-hand with higher employee satisfaction and perceived productivity. Large open-plan offices and centrally controlled air condition show a negative effect on health, satisfaction and productivity. There is some evidence that workplaces in green buildings are healthier than workplaces in conventional buildings. Adjustable workstations with sit-stand desks show to have beneficial effects for comfort and labour productivity. Practitioners should take these findings into account in their design and management activities.

What constitutes a healthy workplace is much dependent on the workstyles and the preferences of the users. The degree to which the workplace has impact on satisfaction is in particular dependent on user preferences in relation to privacy versus social contact. The impact on productivity is in particular dependent on the specific workstyle and how well the workplace supports the work activities. Involving the users in the planning process and change management during implementation is crucial.

Scientific research on monetary cost and benefits of healthy workplaces is limited. Overall, the data indicate a positive impact of healthy workplaces on the reduction of sickness absence.

Because of the impact of many interrelated variables, it is difficult to trace cause-effect relationships between characteristics of healthy work environments and support of other value dimensions. Usually, various interventions are conducted simultaneously. Furthermore, employees' health not only depends on what the workplace does to employees, but also on what workers bring with them to the workplace.

The mixed findings make it hard to provide a sound business case for physical interventions to improve health and well-being. On the one hand, taking care of healthy work environments is a matter of moral responsibility and has in general a positive effect on 


\begin{tabular}{llll}
\hline Study & Methodology & Research topics & Findings \\
\hline
\end{tabular}

Burton (2008) Literature review
Marsden and
Moriconi
(2009)

Elzeyadi (2011)

Terrapin Bright Green (2012)

\section{European}

Table 5.

Agency for

Financial costs and benefits of healthy workplaces (11 studies)

Safety and Work (2014)
Stress, absenteeism, cost Stress contributes to $19 \%$ of absenteeism costs, $30 \%$ of disability costs, at least $60 \%$ of workplace accidents and $40 \%$ of staff turnover costs

Positive impact of healthy workplaces on staff turnover and sick leave, resulting in cost reduction

Cost-benefit ratio may range from $€ 1.25$ to $€ 5$ for every Euro invested. Great cost savings can be gained, when health promotion programs are implemented in a supportive work environment

Health at
Costs and benefit of biophilic design investments involving very low or no up-front cost, such as providing employees access to plants, natural views, daylight and other biophilic design elements

\section{Literature study}

\author{
Good consultation and \\ communication at the local level, \\ and absence management that \\ emphasizes employee well-being, is \\ associated with lower absenteeism \\ In a case study, absence rates fell \\ from $6.5 \%-7 \%$ to $4 \%-5 \%$ \\ Workers in offices with poor ratings \\ of light quality and poorer views \\ used significantly more sick leave \\ hours. Taken together, the two \\ variables explained $6.5 \%$ of the \\ variation in sick leave use, which was \\ statistically significant \\ The combination of view quality, \\ lighting quality and glazing area \\ explained $10 \%$ of the variation in \\ sick leave days

\section{Biophilic relationship} \\ between views on \\ the workplace and \\ impacts on sick leave \\ Absenteeism
} and quantities by 175 questionnaire survey and physical health screening forms of employees' health conditions

Costs of stress and psychosocial risks at work, on national level and per sector interviews with managers
Integrating quality daylighting schemes can save over $€ 1.65$ per employee per year in office costs; over $€ 76 \mathrm{~m}$ could be saved annually in health-care costs as a result of providing patients with views to nature. Biophilic changes can reduce absenteeism over a long period of time, reduce complaints that drain human resource employees

Stress and psychological risks result in increased medical and insurance costs, higher sickness absence, higher staff turnover, early retirement, more accidents productivity and help retain 


\begin{tabular}{|c|c|c|c|c|}
\hline Study & Methodology & Research topics & Findings & \\
\hline & & & $\begin{array}{l}\text { and errors, loss of productivity and } \\
\text { lower quality of life. It is estimated } \\
\text { that } 30 \% \text { of sickness absence is } \\
\text { directly caused by stress. Every } € 1 \\
\text { of expenditure in promotion and } \\
\text { prevention programs generates net } \\
\text { economic benefits over a one-year }\end{array}$ & work \\
\hline $\begin{array}{l}\text { Bodin } \\
\text { Danielsson } \\
\text { et al. }(2014)\end{array}$ & $\begin{array}{l}\text { Data from 1,852 } \\
\text { employees working in } \\
\text { Sweden in different office } \\
\text { types }\end{array}$ & Sick leave & $\begin{array}{l}\text { period of up to } € 13.62 \\
\text { Significant higher short sick leave } \\
\text { among women in small, medium- } \\
\text { sized and large open-plan offices } \\
\text { and among men in flex-offices } \\
\text { A significantly higher risk on long } \\
\text { sick leave was found among } \\
\text { women in large open-plan and for } \\
\text { the total number of sick days } \\
\text { among men in flex offices }\end{array}$ & \\
\hline Laski (2016) & Analysis of 11 cases & $\begin{array}{l}\text { Impact of green features, } \\
\text { location and amenities, } \\
\text { IAQ, acoustics, look-and- } \\
\text { feel on health and well- } \\
\text { being benefits, occupant } \\
\text { satisfaction and economic } \\
\text { benefits }\end{array}$ & $\begin{array}{l}\text { Because of the variety in projects } \\
\text { regarding its size, type of } \\
\text { organization and interventions, } \\
\text { calculated economic benefits } \\
\text { showed a wide range with drops in } \\
\text { employee sick days of } 25 \%-58 \% \text {, } \\
\text { reductions in staff turnover of } 27 \% \\
\text { and annual savings up to } € 85,000 \\
\text { per year }\end{array}$ & \\
\hline $\begin{array}{l}\text { Jinnett et al. } \\
\text { (2017) }\end{array}$ & $\begin{array}{l}\text { Study of } 16,926 \text { employees } \\
\text { who } \\
\text { participated in a worksite } \\
\text { wellness program }\end{array}$ & $\begin{array}{l}\text { Workplace safety, } \\
\text { employees' health } \\
\text { conditions and } \\
\text { absenteeism }\end{array}$ & $\begin{array}{l}\text { Poor workplace safety and } \\
\text { employees' chronic health } \\
\text { conditions contributed to } \\
\text { absenteeism and job performance. } \\
\text { Their impact was influenced by } \\
\text { the physical and cognitive } \\
\text { difficulty of the job }\end{array}$ & \\
\hline $\begin{array}{l}\text { Muldavin } \\
\text { et al. }(2017 / \\
\text { 2018) }\end{array}$ & $\begin{array}{l}\text { Property Health and } \\
\text { Wellness ROI (Return of } \\
\text { Investment) }\end{array}$ & $\begin{array}{l}\text { Financial and health } \\
\text { impact of investments in } \\
\text { a hypothetical investment } \\
\text { in the WELL Building } \\
\text { Standard for a 18,500 } \mathrm{m}^{2} \\
\text { office building }\end{array}$ & $\begin{array}{l}\text { Over a period of five years, the } \\
\text { Internal Rate of Return from } \\
\text { WELL investments is estimated to } \\
\text { be almost } 300 \% \text {. Sensitivity } \\
\text { analysis around a range of } \\
\text { potential cost estimates (e.g. more } \\
\text { or less than } 0.5 \% \text { productivity } \\
\text { growth, taking into account initial } \\
\text { investments to learn new rating } \\
\text { systems) results in other figures }\end{array}$ & \\
\hline Marson (2018) & $\begin{array}{l}\text { Analysis of cost data from } \\
\text { Investopedia } \\
\text { and the International Well } \\
\text { Building Institute }\end{array}$ & $\begin{array}{l}\text { Productivity loss and } \\
\text { absenteeism }\end{array}$ & $\begin{array}{l}\text { In the USA, the total annual costs } \\
\text { of lost productivity because of } \\
\text { employee absenteeism counts } \\
€ 69 \text { bn. Creating and implementing } \\
\text { well-being programs can reduce } \\
\text { employee "sick days" by } 26 \% \text {. A } \\
\text { real estate agency that achieved a } \\
\text { WELL Gold certification } \\
\text { mentioned a reduction of four sick }\end{array}$ & \\
\hline
\end{tabular}




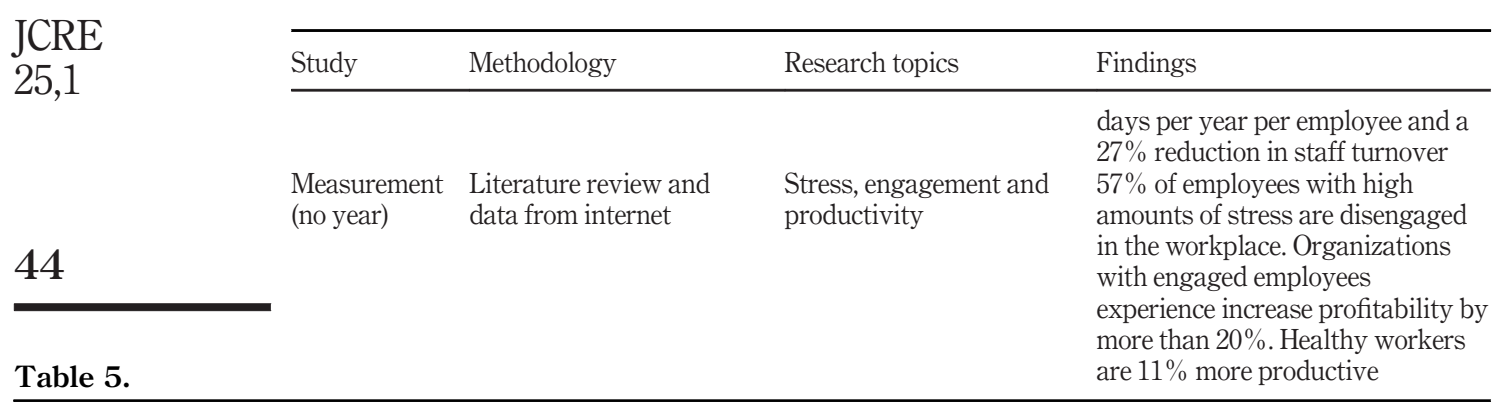

employee satisfaction and labour productivity and on society as a whole. These advantages have to be balanced with the costs of interventions to provide more healthy environments. An obstacle for a more integrated, holistic business case may be that the cost of interventions and its resulting output and outcomes are not always easy to measure in a quantitative way. Another difficulty is that some outcomes might be experienced in the short term and perhaps only temporarily, while others might be sustained, reduced or only experienced in the long term. One solution is to base business cases not only on quantitative data but to take into account well-argued qualitative considerations as well. As such, we plea for a so-called value based business case or "value case".

\subsection{Suggestions for further research}

Additional research is needed to get a deeper, holistic and evidence-based knowledge of the added value of healthy workplaces and interrelationships between health, satisfaction and productivity and financial impacts that integrate different research topics and research methods. A next step can be to use the research findings as input to follow-up transdisciplinary research by academics from different fields, including corporate real estate management, facilities management, human resource management, environmental psychology and work and organizational psychology. Reflections on data by an interdisciplinary team and experimenting with particular interventions may be helpful as well.

Other topics for future research are extension of this literature review with papers from other journals and databases such as Scopus and PubMed, and to conduct additional empirical research with before-after studies of particular interventions and data-collecting techniques such as workshops, group interviews, pilot projects and selfmeasurement of health and health-supportive behaviour, e.g. by using wearables and apps. Cost studies should not only focus on data analysis of sickness absence, but extend their scope to self-reported health risks and health conditions, to get a better understanding of what drives health costs and lost productivity (Jinnett et al., 2017). Besides, more studies are needed into the costs of particular interventions and return on investment.

A particular topic for further research is the use and experience of offices in the post Covid-19 period. Increased "infection risk mitigation" will affect the presence in the office, number of people per $\mathrm{m}^{2}$, need for fresh air access, etc. The Covid-19 crisis has resulted in a drastic increase in home working and this experience is likely to have profound implications for office work in the future. 


\section{References}

Al Horr, Y., Arif, M., Kaushik, A., Mazroei, A., Katafygiotou, M. and Elsarrag, E. (2016), “Occupant productivity and office indoor environment quality: a review of the literature", Building and Environment, Vol. 105, pp. 369-389, doi: 10.1016/j.buildenv.2016.06.001.

\section{Impact of healthy workplaces}

Appel-Meulenbroek, R., Van der Voordt, T., Le Blanc, P., Aussems, R. and Arentze, T. (2020), "Impact of activity-based workplaces on burnout and engagement", Journal of Corporate Real Estate, Vol. 22 No. 4, pp. 279-296, doi: 10.1108/JCRE-09-2019-0041.

Bauer, A. (2020), "Pride and productivity: post occupancy evaluation of the healing office design concept", Journal of Corporate Real Estate, Vol. 22 No. 4, pp. 313-340, doi: 10.1108/JCRE-02-20190012.

Bodin Danielsson, C. and Bodin, L. (2008), "Office-type in relation to health, well-being and job satisfaction among employees", Environment and Behavior, Vol. 40 No. 5, pp. 636-668, doi: $10.1177 / 0013916507307459$ ।

Bodin Danielsson, C.B., Chungkham, H.S., Wulff, C. and Westerlund, H. (2014), “Office design's impact on sick leave rates", Ergonomics, Vol. 57 No. 2, pp. 139-147, doi: 10.1080/00140139.2013.871064.

British Council for Offices (2018), "Wellness matters", Report, available at: www.bco.org.uk/ HealthWellbeing/WellnessMatters.aspx

Burton, J. (2008), The Business Case for a Healthy Workplace, Toronto, Industrial Accident Prevention Association IAPA.

Candido, C., Marzban, S., Haddad, S., Mackey, M. and Loder, A. (2021), "Designing healthy workspaces: results from Australian certified open-plan offices”, Facilities, Vol. 39 Nos 5/6, pp. 411-433, doi: $10.1108 / \mathrm{F}-02-2020-0018$.

Candido, C., Thomas, L., Haddad, S., Zhang, F., Mackey, M. and Ye, W. (2019), "Designing activitybased workspaces: satisfaction, productivity and physical activity", Building Research and Information, Vol. 47 No. 3, pp. 275-289, doi: 10.1080/09613218.2018.1476372.

Candido, C., Zhang, J., Kim, J., De Dear, R., Thomas, L., Strapasson, P. and Joo, C. (2016), "Impact of workspace layout on occupant satisfaction, perceived health and productivity", Proceedings of 9th Windsor Conference: Making Comfort Relevant, Windsor, available at: http://nceub.org.uk/

Chambers, A.J., Robertson, M.M. and Baker, N.A. (2019), "The effect of sit-stand desks on office worker behavioral and health outcomes: a scoping review", Applied Ergonomics, Vol. 78, pp. 37-53, doi: 10.1016/j.apergo.2019.01.015.

Clements-Croome, D. (2018), "Effects of the built environment on health and well-being", in ClementsCroome, D. (Ed.), Creating the Productive Workplace: Places to Work Creatively, 3rd ed., London, Routledge, pp. 3-40.

Colenberg, S., Jylhä, T. and Arkesteijn, M. (2020), "The relationship between interior office space and employee health and well-being", Building Research and Information, Vol. 49 No. 3, doi: 10.1080/ 09613218.2019.1710098.

Cordero, A.B., Babapour, M. and Karlsson, M. (2020), "Feel well and do well at work: a post-relocation study on the relationships between employee wellbeing and office landscape", Journal of Corporate Real Estate, Vol. 22 No. 2, pp. 113-137, doi: 10.1108/JCRE-01-2019-0002.

Davis, M.C., Leach, D.J. and Clegg, D.J. (2020), "Breaking out of open-plan: extending social interference theory through an evaluation of contemporary offices", Environment and Behavior, Vol. 52 No. 9, pp. 945-978, doi: 10.1177/0013916519878211.

Eichholtz, P., Kok, N. and Palacios, P. (2019), "Moving to productivity: the benefits of healthy buildings", Preliminary Working Paper, Maastricht University, doi: 10.7910/DVN/ALUUEC.

Elnaklah, R., Walker, I. and Natarajan, S. (2021), "Moving to a green building: indoor environment quality, thermal comfort and health", Building and Environment, Vol. 191, pp. 1-19, doi: 10.1016/ j.buildenv.2021.107592. 
JCRE 25,1

Elzeyadi, I. (2011), "Daylighting-Bias and biophilia: quantifying the impacts of daylight on occupants health", Thought and Leadership in Green Buildings Research. Greenbuild Proceedings, Washington, DC, USGBC Press.

Engelen, L., Chau, J., Young, S., Mackey, M., Jeyapalan, D. and Bauman, A. (2019), "Is activity-based working impacting health, work performance and perceptions? A systematic review", Building Research and Information, Vol. 47 No. 4, pp. 468-479, doi: 10.1080/ 09613218.2018.1440958.

European Agency for Safety and Health at Work (2014), Calculating the Cost of Work-Related Stress and Psychosocial Risks, Luxembourg, Publications Office of the European Union. 10.2802/20493

Ferrari, R. (2015), "Writing narrative style literature reviews", The European Medical Writers Association, doi: 10.1179/2047480615Z.000000000329.

Forooraghi, M., Miedema, E., Ryd, N. and Wallbaum, H. (2020), "Scoping review of health in office design approaches", Journal of Corporate Real Estate, Vol. 22 No. 2, pp. 155-180, doi: 10.1108/ JCRE-08-2019-0036.

Franke, M. and Nadler, C. (2020), "Towards a holistic approach for assessing the impact of IEQ on satisfaction, health, and productivity", Building Research and Information, Vol. 49 No. 4, pp. 417-444, doi: 10.1080/09613218.2020.1788917.

Garland, E., Watts, A., Doucette, J., Foley, M., Senerat, A. and Sanchez, S. (2018), "Stand up to work: assessing the health impact of adjustable workstations", International Journal of Workplace Health Management, Vol. 11 No. 2, pp. 85-95, doi: 10.1108/IJWHM-10-2017-0078.

Green, B.N., Johnson, C.D. and Adams, A. (2006), "Writing narrative literature reviews for peerreviewed journals: secrets of the trade", Journal of Chiropractic Medicine, Vol. 5 No. 3, pp. 101-117, doi: 10.1016/S0899-3467(07)60142-6.

Groen, B., van der Voordt, T., Hoekstra, B. and van Sprang, H. (2019), "Impact of employee satisfaction with facilities on self-assessed productivity support", Journal of Facilities Management, Vol. 17 No. 5, pp. 442-462, doi: 10.1108/JFM-12-2018-0069.

Haapakangas, A., Hallman, D.M., Mathiassen, S.E. and Jahncke, H. (2018b), "Self-rated productivity and employee well-being in activity-based offices: the role of environmental perceptions and workspace use", Building and Environment, Vol. 145, pp. 115-124.

Haapakangas, A., Hongisto, V., Varjo, J. and Lahtinen, M. (2018a), "Benefits of quiet workspaces in open-plan offices: evidence from two office relocations", Journal of Environmental Psychology, Vol. 56, pp. 63-75, doi: 10.1016/j.jenvp.2018.03.003.

Hähn, N., Essah, E. and Blanusa, T. (2020), "Biophilic design and office planting: a case study of effects on perceived health, well-being and performance metrics", Intelligent Buildings International, doi: 10.1080/17508975.2020.1732859.

Herbig, B., Schneider, A. and Nowak, D. (2016), "Does office space occupation matter? The role of the number of persons per enclosed office space, psychosocial work characteristics, and environmental satisfaction in the physical and mental health of employees", Indoor Air 2016, Vol. 26 No. 5, pp. 755-767, doi: 10.1111/ina.12263.

Hodzic, S., Kubicek, B., Uhlig, L. and Korunka, C. (2021), "Activity-based flexible offices: effects on work-related outcomes in a longitudinal study", Ergonomics, Vol. 64 No. 4, pp. 455-473, doi: 10.1080/00140139.2020.1850882.

Isham, A., Mair, S. and Jackson, T. (2019), Wellbeing and Productivity: A Review of the Literature, Report for the Economic and Social Research Council, December 2019.

Jamrozik, A., Clements, N., Hasana, S.S., Zhaoa, J., Zhanga, R., Campanellaa, C., Loftness, V., Portera, P., Lya, S., Wanga, S. and Bauera, B. (2019), "Access to daylight and view in an office improves cognitive performance and satisfaction and reduces eyestrain: a controlled crossover study", Building and Environment, Vol. 165, p. 106379, doi: 10.1016/j. buildenv.2019.106379. 
Jensen, P.A. and Van der Voordt, T. (Eds) (2017), Facilities Management and Corporate Real Estate Management as Value Drivers: How to Manage and Measure Adding Value, London/New York, NY, Routledge

Jensen, P.A. and Van der Voordt, T. (2020), "Healthy workplaces: what we know and what we should know", Journal of Corporate Real Estate, Vol. 22 No. 2, pp. 95-112, doi: 10.1108/JCRE-11-20180045.

Jinnett, K., Schwatka, N., Tenney, L., Brockbank, C.V.S. and Newman, L. (2017), “Chronic conditions, workplace safety, and job demands contribute to absenteeism and job performance", Health Affairs, Vol. 36 No. 2, pp. 237-244, doi: 10.1377/hlthaff.2016.1151.

Kar, G. and Hedge, A. (2021), "Effect of workstation configuration on musculoskeletal discomfort, productivity, postural risks, and perceived fatigue in a sit-stand-walk intervention for computerbased work", Applied Ergonomics, Vol. 90, pp. 1-11, doi: 10.1016/j.apergo.2020.103211.

Karakolis, T. and Callaghan, J.P. (2014), "The impact of sit-stand office workstations on worker discomfort and productivity: a review", Applied Ergonomics, Vol. 45 No. 3, pp. 799-806, doi: 10.1016/j.apergo.2013.10.001.

Kaushik, A., Arif, M., Tumula, P. and Ebohon, O.J. (2020), "Effect of thermal comfort on occupant productivity in office buildings: response surface analysis", Building and Environment, Vol. 180, pp. 1-9, doi: 10.1016/j.buildenv.2020.107021.

Kim, J., Candido, C., Thomas, L. and De Dear, R. (2016), "Desk ownership in the workplace: the effect of non-territorial working on employee workplace satisfaction, perceived productivity and health", Building and Environment, Vol. 103, pp. 203-214, doi: 10.1016/j.buildenv.2016.04.015.

Ko, W.H., Schiavon, S., Zhang, Z., Graham, L.T., Brager, G., Mauss, I. and Lin, Y.-W. (2020), "The impact of a view from a window on thermal comfort, emotion, and cognitive performance", Building and Environment, Vol. 175, pp. 1-15, doi: 10.1016/j.buildenv.2020.106779.

Lamb, S. and Kwok, K.C.S. (2016), "A longitudinal investigation of work environment stressors on the performance and wellbeing of office workers", Applied Ergonomics, Vol. 52, pp. 104-111, doi: 10.1016/j.apergo.2015.07.010.

Lamb, S. and Kwok, K.C.S. (2017), "Sopite syndrome in wind-excited buildings: productivity and wellbeing impacts", Building Research and Information, Vol. 45 No. 3, pp. 347-358, doi: 10.1080/ 09613218.2016.1190140.

Laski, J. (2016), "Doing right by planet and people", The Business Case for Health and Wellbeing in Green Building, London/Toronto, World Green Building Council.

Licina, D. and Yildirim, S. (2021), "Occupant satisfaction with indoor environmental quality, sick building syndrome (SBS) symptoms and self-reported productivity before and after relocation into WELL-certified office buildings", Building and Environment, Vol. 204, pp. 1-12, doi: 10.1016/ j.buildenv.2021.108183.

Lu, M., Hu, S., Mao, Z., Liang, P., Xin, S. and Guan, H. (2020), "Research on work efficiency and light comfort based on EEG evaluation method", Building and Environment, Vol. 183, pp. 1-11, doi: 10.1016/j.buildenv.2020.107122.

MacNaughton, P., Satish, U., Laurent, J.G.C., Flanigan, S., Vallarino, J., Coull, B., Spengler, J.D. and Allen, J.G. (2017), "The impact of working in a green certified building on cognitive function and health”, Building and Environment, Vol. 114, pp. 178-186, doi: 10.1016/j.buildenv.2016.11.041.

Marsden, D. and Moriconi, S. (2009), “'The value of rude health': employees' well being, absence and workplace performance", CEP Discussion Paper No 919. London, The London School of Economics, Centre for Economic Performance.

Marsh, P. and French, S. (2020), "The GSK workspace performance hub: promoting productivity and wellbeing through office design", Corporate Real Estate Journal, Vol. 9 No. 4, pp. 345-360.

Marson, M. (2018), "The business value of an innovative building”, Corporate Real Estate Journal, Vol. 8 No. 2, pp. 154-164. 
JCRE 25,1

Morrison, R.L. and Smollan, R.K. (2020), “Open plan office space? If you're going to do it, do it right: a fourteen-month longitudinal case study", Applied Ergonomics, Vol. 82, pp. 1-18, doi: 10.1016/j. apergo.2019.102933.

Muldavin, S., Miers, C.R. and McMackin, K. (2017/2018), "Buildings emerge as drivers of health and profits", Corporate Real Estate Journal, Vol. 7 No. 2, pp. 177-193.

Nappi, I., De Campos Ribeiro, G. and Cochard, N. (2020), "The interplay of stress and workspace attachment on user satisfaction and workspace support to labour productivity", Journal of Corporate Real Estate, Vol. 22 No. 3, pp. 215-237, doi: 10.1108/JCRE-05-2019-0026.

Nelson, E. and Holzer, D. (2017), The Healthy Office Revolution, Amstelveen, Learn Adapt Build Publishing.

Rasheed, E.O., Khoshbakht, M. and Baird, G. (2021), "Time spent in the office and workers' productivity, comfort and health: a perception study", Building and Environment, Vol. 195, pp. 1-9, doi: 10.1016/j.buildenv.2021.107747.

Roskams, M. and Haynes, B. (2019), "An experience sampling approach to the workplace environment survey”, Facilities, Vol. 38 Nos 1/2, pp. 72-85, doi: 10.1108/F-04-2019-0050.

Seddigh, A., Berntson, E., Bodin Danielson, C. and Westerlund, H. (2014), "Concentration requirements modify the effect of office type on indicators of health and performance", Journal of Environmental Psychology, Vol. 38, pp. 167-174, doi: 10.1016/j.jenvp.2014.01.009.

Soriano, A., Kozusnik, M.W. and Peiró, J.M. (2020), "The role of employees' work patterns and office type fit (and misfit) in the relationships between employee Well-Being and performance", Environment and Behavior, Vol. 52 No. 2, pp. 111-138, doi: 10.1177/0013916518794260.

Tan, Z., Roberts, A.C., Lee, E.L., Kwok, K.-W., Car, J., Soh, C.K. and Christopoulos, G. (2020), "Transitional areas affect perception of workspaces and employee well-being: a study of underground and above-ground workspaces", Building and Environment, Vol. 179, pp. 1-10, doi: 10.1016/j.buildenv.2020.106840.

Terrapin Bright Green (2012), "The economics of biophilia”, Why Designing with Nature in Mind Makes Financial Sense, New York, NY and Washington, DC.

Thatcher, A., Adamson, K., Bloch, L. and Kalantzis, A. (2020), "Do indoor plants improve performance and well-being in offices? Divergent results from laboratory and field studies", Journal of Environmental Psychology, Vol. 71 No. 1.11, p. 101487, doi: 10.1016/j.jenvp.2020.101487.

Van der Voordt, T. (2021), "Designing for health and wellbeing: various concepts, similar goals", Gestão and Tecnologia de Projetos, Vol. 16 No. 4, pp. 13-31, doi: 10.11606/gtp.v16i4.178190.

Van der Voordt, T. and Jensen, P.A. (2014), "Adding value by FM: exploration of management practice in The Netherlands and Denmark", EFMC 2014, Berlin, 4-6 June 2014.

Wargocki, P. (2019), "Productivity and health effects of high indoor air quality", Encyclopedia of Environmental Health, 2nd edition, Vol. 5, pp. 382-388, doi: 10.1016/B978-0-12-409548-9.01993-X.

Wijk, K., Bergsten, E.L. and Hallman, D.M. (2020), "Sense of coherence, health, Well-Being, and work satisfaction before and after implementing activity-based workplaces", International Journal of Environmental Research and Public Health, Vol. 17 No. 14, p. 5250, doi: 10.3390/ijerph17145250.

Wolkoff, P. (2020), "Dry eye symptoms in offices and deteriorated work performance. A perspective", Building and Environment, Vol. 172, p. 106704, doi: 10.1016/j.buildenv.2020.106704.

Zerguine, H., Johnston, V., Healy, G.N., Abbott, A. and Goode, A.D. (2021), "Usage of sit-stand workstations: benefits and barriers from decision makers' perspective in Australia”, Applied Ergonomics, Vol. 94, pp. 1-11, doi: 10.1016/j.apergo.2021.103426.

\section{Further reading}

Jensen, P.A. and Van der Voordt, T. (2021), "Productivity as a value parameter for FM and CREM", Facilities, Vol. 39 Nos 5/6, pp. 305-320, doi: 10.1108/F-04-2020-0038. 
Measuremen consultancy (no year), "Why should you incorporate a healthy workplace strategy?", available at: www.measuremen.io/wp-content/uploads/2018/10/Measuremen-Whitepaper-Whyshould-you-incorporate-a-healthy-workplace-strategy.pdf

Pejtersen, J.H., Feveile, H., Christensen, K.B. and Burr, H. (2011), "Sickness absence associated with shared and open-plan offices - a national cross sectional questionnaire survey", Scandinavian Journal of Work, Environment and Health, Vol. 37 No. 5, pp. 376-382, doi: 10.5271/sjweh.3167.

Platts, L.G., Seddigh, A., Berntson, E. and Westerlund, H. (2020), "Sickness absence and sickness presence in relation to office type: an observational study of employer-recorded and self-reported data from Sweden”, Plos One, Vol. 15 No. 4, p. e0231934, doi: 10.1371/journal.pone.0231934.

Roskams, M. and Haynes, B. (2020), "Salutogenic design in the workplace: Supporting sense of coherence through resources in the workplace environment", Journal of Corporate Real Estate, Vol. 22 No. 2, pp. 193-153, doi: 10.1108/JCRE-01-2019-0001.

WHO (2021), "Constitution of the world health organization", available at: www.who.int/about/ governance/constitution. (accessed August 30, 2021).

World Green Building Council (2014), "Health, wellbeing and productivity in offices: the next chapter for green building", available at: www.worldgbc.org/sites/default/files/compressed_

\section{Corresponding author}

Theo van der Voordt can be contacted at: theovandervoordt@gmail.com

For instructions on how to order reprints of this article, please visit our website: 